\title{
Clinical Reasoning: A 58-year-old man with distal hand weakness
}

Neurology ${ }^{\circledR}$ 2019;93:465. doi:10.1212/WNL.0000000000008184

In the article "Clinical Reasoning: A 58-year-old man with distal hand weakness" by Vacchiano et al., ${ }^{1}$ the affiliation for Prof. Rocco Liguori should have read "Department of Biomedical and Neuromotor Sciences, University of Bologna, Italy; IRCCS Istituto delle Scienze Neurologiche di Bologna, Italy.” The authors regret the error.

\section{Reference}

1. Vacchiano V, Di Stasi V, Donadio V, Sturiale C, Liguori R. Clinical Reasoning: A 58-year-old man with distal hand weakness. Neurology 2019;92:e1395-e1400.

\section{MRI predicts intracranial hemorrhage in patients who receive long- term oral anticoagulation}

Neurology ${ }^{\circledR}$ 2019;93:465. doi:10.1212/WNL.0000000000007920

In the article "MRI predicts intracranial hemorrhage in patients who receive long-term oral anticoagulation" by Martí-Fàbregas et al., ${ }^{1}$ first published online April 19, 2019, Dr. MedranoMartorell's affiliation should read: Hospital del Mar-Universitat Autònoma Barcelona (UAB), Barcelona, Spain. The authors regret the error.

\section{Reference}

1. Martí-Fàbregas J, Medrano-Martorell S, Merino E, et al. MRI predicts intracranial hemorrhage in patients who receive long-term oral anticoagulation. Neurology 2019;92:e2432-e2443.

\section{Midlife adiposity predicts cognitive decline in the prospective Multicenter AIDS Cohort Study \\ Neurology ${ }^{\circledR}$ 2019;93:465. doi:10.1212/WNL.0000000000008187}

In the article "Midlife adiposity predicts cognitive decline in the prospective Multicenter AIDS Cohort Study" by Rubin et al., ${ }^{1}$ first published online June 14, 2019, in figure 3, label A should read "HIV-." The label appears correctly in the final print version of this article published on July 16, 2019. The publisher regrets the error.

\section{Reference}

1. Rubin LH, Gustafson D, Hawkins KL, et al. Midlife adiposity predicts cognitive decline in the prospective Multicenter AIDS Cohort Study. Neurology 2019;93:e261-e271.

\section{Comparing the acute presentation of sport-related concussion in the adult and pediatric populations \\ Neurology ${ }^{\circledR}$ 2019;93:465. doi:10.1212/WNL.0000000000007917}

In the abstract "Comparing the acute presentation of sport-related concussion in the adult and pediatric populations" by Corti et al., ${ }^{1}$ first published online December 5, 2018, and in the 2018 Sports Concussion Conference Abstracts Supplement, Dr. Pizzimenti's first name should be Natalie. The authors regret the error.

\section{Reference}

1. Corti SJ, Pizzimenti N, McCarthy MT, et al. Comparing the acute presentation of sport-related concussion in the adult and pediatric populations. Neurology 2018;91(suppl 1):S12. 


\section{Neurology}

\section{MRI predicts intracranial hemorrhage in patients who receive long-term oral anticoagulation}

Neurology 2019;93;465

DOI 10.1212/WNL.0000000000007920

This information is current as of September 2, 2019

\section{Updated Information \&} Services

References

Permissions \& Licensing

Reprints including high resolution figures, can be found at: http://n.neurology.org/content/93/10/465.2.full

This article cites 1 articles, 1 of which you can access for free at: http://n.neurology.org/content/93/10/465.2.full\#ref-list-1

Information about reproducing this article in parts (figures,tables) or in its entirety can be found online at:

http://www.neurology.org/about/about_the_journal\#permissions

Information about ordering reprints can be found online:

http://n.neurology.org/subscribers/advertise

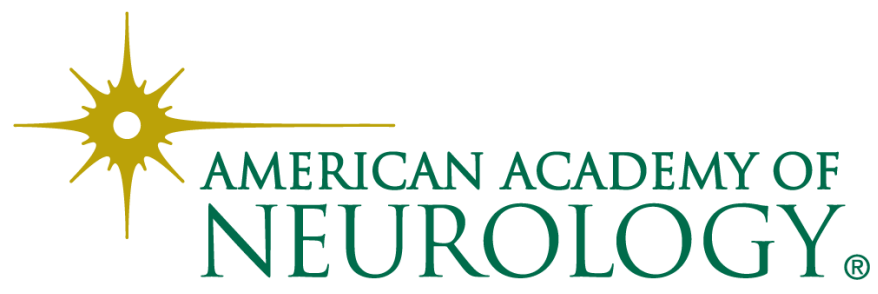

